特集 16

\title{
肝硬変症および閉塞性黄瘟例における術後黄疸
}

\author{
東北大学第 1 外科 \\ 大内 清昭 藤谷 恒明 Luis Hashimoto \\ 松原 修二 松野 正紀

\section{POSTOPERATIVE JAUNDICE IN PATIENTS WITH LIVER CIRRHOSIS OR OBSTRUCTIVE JAUNDICE} \\ Kiyoaki OUCHI, Tsuneaki FUJIYA, Luis HASHIMOTO, \\ Shuji MATSUBARA and Seiki MATSUNO \\ lst Department of Surgery, Tohoku University School of Medicine
}

3 年間に教室で施行した手術例中, 肝機能正常例での術後黄連発生頻度は7.7\%であったのに対し, 肝硬変合併例でのそれは $67 \%$ と高く，高度黄疸を呈した全例が死亡している．誘因として肝障害高度 例に対する過大侵襲や，術中，術後の出血，重症感染症が考号られた。 また，閉塞性黄疸術後死亡例 の多くは出血が肝腎不全の誘因となっていた，実験的検討では，肝硬変，長期閉塞性黄㾝では低血圧 負荷後の肝腎局所循環の回復は不良であり，エネルギー代謝障害も遷延した，以上から，これら肝障 害例では肝障害度に応じた適切な術式を選択すべきであり，出血による低血圧の招来は極力避けるべ きである。

㮂引用語：術後黄症, 肝硬变症, 閉塞性黄㡺

はじめに

術後一過性に発現する軽度の黄㾝はしばしば経験す るところであり，多くの場合はなんら治療を要しない まま黄疸は軽快する。しかし, まれには黄㾝が高度と なり治療に苦慮する症例す存在する。特に肝硬変症や 閉塞性黄疸など術前より肝障害を有している症例では 術後黄㾝の発生頻度は増加し, 高度黄㾝に至る症例の 救命は極めて困難である。今回, 教室で過去 3 年間に 施行した手術例を術前肝機能正常群, 肝硬変群, 肝切 除群, 閉塞珄黄疸群の 4 群に分け, 術後黄疸の頻度, 誘因などを中心に検討を加えた。をた，これら肝障害 例では術中術後の出血を契機に肝不全, 腎不全に陥る ことが多いため, 低血圧負荷の肝, 腎局所循環および エネルギー代謝に与える影響を㬰験的に検討したので 報告する。

*第32回日消外会総会シンポ 2 ・肝障害と手術侵襲 $<1988$ 年 9 月 14 日受理 $>$ 別刷請求先 : 大内 清昭 干980 仙台市星陵町 $1-1$ 東北大学医学部第 1 外 科

\section{方法}

1. 臨㦿的検討

1983年から.1985年までの 3 年間に施行した手術例の らち, 術前肝機能および術中肝肉眼所見が正常であっ た症例は1080例であり，手術の内訳は胃垔全摘164例， 胃全摘または噴門側切除82例, 胆摘141例, 総胆管切 開・Tドレナーシ63例, 大腸切除125例, 直腸切断28例 などである，肝硬変症では54例に対し各種手術を施行 した。疾患別では食道静脈瘤29例, 胃癌 7 例, 胆囊結 石症 6 例, 肝癌（肝切除非施行） 5 例, 胃潰瘍, 直腸 癌各 3 例, 虫垂炎 1 例である. 肝切除は44例に対し施 行して拈り，与ち肝硬変非併存23例, 肝硬変併存 21 例 である. 前者は肝血管腫, 肝内結石症各 4 例, 胆道癌 3 例, 肝癌, 肝霊胞腺癌各 1 例, 後者は全例肝細胞癌 である、術後血清ビリルビン値が $2 \mathrm{mg} / \mathrm{dl}$ を越えた症 例を術後黄疸とし， $2 \sim 5 \mathrm{mg} / \mathrm{dl}$ を軽度，5〜10 $\mathrm{mg} /$ $\mathrm{dl}$ を中等度, $10 \mathrm{mg} / \mathrm{dl}$ 以上を高度黄疸とした。 なた， 閉塞性黄疸手術例は60例あり, 良性閉塞が 12 例, 悪性 閉塞が48例であった，前者では 9 例が，後者では34例 が術前にPTBDを施行されている。 


\section{2. 実験的検討}

肝硬変モデルはSD系雄性 ラットに0.04\% thioacetamide 水溶液を 6 力月間领用水として与兄作 製した。大腿静脈より $20 \mathrm{ml} / \mathrm{kg}$ 体重の血液を脱血し低 血圧負荷を与えた。1 時間後脱血した血液を全量還血 し，以後 4 時間まで肝，腎組織血流量を測定した。測 定には電解式組織血流計（バイオメディカル社製 RBF-II）を用いた。また，還血30分後に肝，腎組織を 採取し，酵素法により ATP, ADP, AMP を測定した。 Energy Charge は Atkinsonの式により算出した ${ }^{1)}$ 。 た，閉塞性黄病モデルは総胆管を結紮切離することに より作製し，黄疸 1，3 週後のラットに対し前記と同 様の低血圧負荷実験を施行した. 正常対照群, 肝硬变, 黄㾝 $1 ， 3$ 週群ともに 5 〜 7 匹を用い 1 群とした。

\section{結果}

\section{1. 臨床的検討}

1) 術前肝機能正常例

手術例数 1080 例のらち, 術後黄㾝は83例 $(7.7 \%)$ に みられた（図 1)。5ち入院中死亡は10例である。術式 別では胆摘が $4.3 \%$ と低い発生頻度であったのに対し， 胃亜全摘 $7.9 \%$, 直腸切断 $10.7 \%$, 胃全摘・噴門側切除 $13.4 \%$ と手術侵襲に応じて高くなる傾向がみられた。 83 例中 67 例 $(80.7 \%)$ と多くは軽度黄疸例であり，中 等度黄㾝は 9 例, 高度黄疸は 7 例で認められた。軽度 黄㾝を呈した67例中59例は術後 15 日以内に黄疸のピー クを有し，死亡の 1 例を除いて一過性の増加であった。 一方, 中等度黄㾝 9 例中 8 例, 高度黄疸全例 日目以後に黄疸のピークを示した. 術後 15 日以内に一 過性の黄疸を呈した症例の多くはなんら黄疸の誘因を 指摘できず，一方，術後15日以後に黄疸のピークを認 めた症例では, 出血性ショック, 膿瘍などの感染症, 肝炎, 制癌剂投与との関連を示唆するものが多数を占 めた. 高度黄疸 7 例中 5 例が入院中に死亡している。 直腸切断抢よび胃全摘術後の出血性ショックに基づく 2 例に対しては，血漿交換などを施行するも救命でき ず，他の 3 例はいずれも腹膜炎からェンドトキシン血 症を呈し，いわゆる肝不全を一側面とする MOF にて 死亡している.

\section{2) 肝硬変合併例}

術後黄㾞は54例中 36 例（66.7\%）にみられた。36例 中23例之多くは軽度黄疸であり，上昇子一過性であっ た。中等度黄㾝は 5 例にみられ，5ち 4 例は胃上部血 管郭清術，噴門側胃切除術など比較的術中出血量の多 い症例であったが，その後黄㾝は軽減している。軽,
図 1 術前肝機能正常例における術式別黄㾝発生頻度

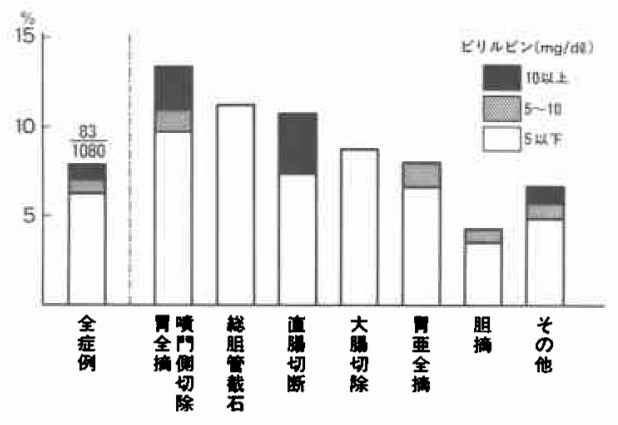

中等度黄疸例で入院死亡は 3 例にみられた。一方, 高 度黄疸は 8 例にみられ，全例が死亡している。この 8 例を含を11例の入院中死亡例の肝不全の誘因として， 緊急手術例が 4 例と多いためか術前に Child Cの高度 肝機能障害を有しているものが 6 例と多数を占めてい た。術前よりすでにビリルビンが高值であった 5 例中 4 例は死亡している。 また，術中術後の大量出血によ り血圧低下を認めたものが 3 例，術後の腹腔内および

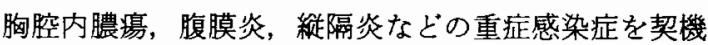
として肝不全に陷ったものが 5 例みられた。

3）肝切除例

肝硬変非併存例に対する肝切除は23例に対し行われ て拉り，らち術後黄㾝を呈したものは13例（56.5\%） であった。ビリルビンの最高值は肝内結石症に対する 肝左葉切除施行例の $6.4 \mathrm{mg} / \mathrm{dl}$ であり，ほか全例がそ れ以下であった。

肝硬変合併肝癌 21 例のうち, 術後黄疸は15例 $(71 \%)$ にみられた．15例のらちビリルビンのピークが10mg/ dl 以下の症例は 9 例あり，いずれる軽快退院してい る. 一方, $10 \mathrm{mg} / \mathrm{dl}$ 以上の症例は 6 例あり，うち 5 例 が入院中に死亡している．黄疸がピークに達するまで の日数は大部分が 2 週以内と, 術後急速に黄㾝の増強 がみられる症例が多い，肝不全の誘因として 2 例に招 いては術中大量出血が，2例においては MMC カプセ ルによる術前 TAEが影響しているものと考兄られ た. 前区域切除施行の 1 例は横隔膜下膿瘍と軽度の意 識障害を合併したものの，そのドレナージと6回の血 浆交換により黄疸は順調に軽減している。

4) 閉塞性黄疸例

教室では通常 PTBDによりビリルビン值が $5 \mathrm{mg} / \mathrm{dl}$ 以下に減黄されたとさろで手術を施行して抢り，多く の症例で術後一過性の黄㾇の増強を認めるものの, そ 
図 2 肝硬変 (LC) ラットの肝, 腎組織血流量に対す る脱血負荷の影響
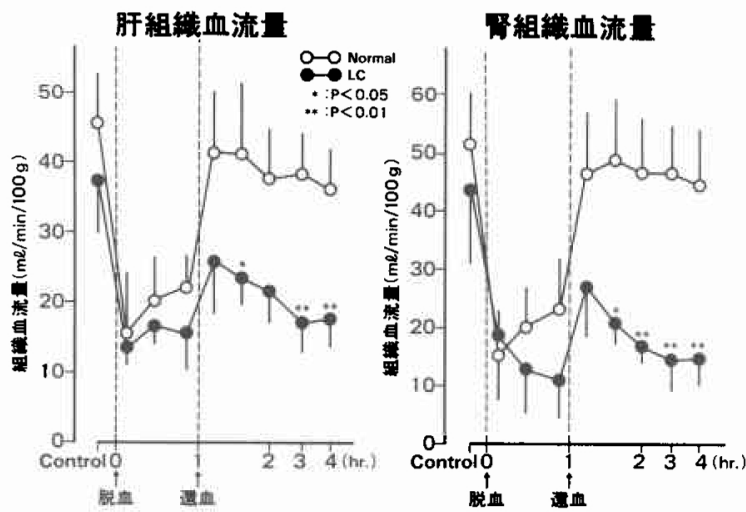

の後順調に軽減している。一方, 死亡退院は良性閉塞 12例中 3 例, 悪性閉塞48例中 10 例にみられ，これらで は黄疾はむしろ増強して死に至ることが多い，良性閉 塞死亡の 3 例中 2 例は術後出血が， 1 例は胆管炎によ る減黄不良のまま手術後の腎不全が誘因となってい た。 また，悪性閉塞入院中死亡10例のうち，姑息的手 術による癌遺残が死亡に大きく関与したと判定された 7 例を除く 3 例では，いずれす術後出血がそれに引き 続く肝腎不全, DICなどの合併症の誘因となってい た.

\section{2. 実験的検討}

1) 肝硬変モデル

動脈王は正常群, 肝硬変群ともに脱血により 60 $\mathrm{mmHg}$ 前後に低下し持続したが，1時間後の還血によ りともに速やかに回復した。汗組織血流量 $(\mathrm{ml} / \mathrm{min} /$ $100 \mathrm{~g}$ 体重) は正常群 $46.2 \pm 7.2$, 肝硬変群 $37.2 \pm 8.7$ で あり, 後者で有意の低下を認めた，脱血負荷により両 群とも15前後に低下したが, 正常群では還血30分後に は負荷前値の約 $96 \% ， 4$ 時間後には83\%に回復した(図 2). 一方, 肝硬変群では還血30分後には前値の $64 \%$ $(\mathrm{p}<0.05), 4$ 時間後には $45 \%(\mathrm{p}<0.01)$ と低下した ますであった。腎組織血流量は正常群52.3土9.8, 肝硬 変群 $42.9 \pm 12.5$ と両群間に差はみられず, 脱血により 両群とも10２0前後に低下した. 正常群では還血によ り 30 分後 $88 \%$ ４時間後 $82 \%$ と回復がみられたのに対 し，肝硬変群ではそれぞれ $49 \%(\mathrm{p}<0.05) ， 29 \%(\mathrm{p}<$ 0.01）と回復は不良であった。還血30分後の肝，堅 Energy Chargeは正常群ではおのおの0.87士0.01, $0.86 \pm 0.02$ と低下は認められなかったのに対し, 肝硬 変群では $0.80 \pm 0.01,0.80 \pm 0.02$ とともに有意の低下
因 3 閉塞性黄㾝ラットの肝, 腎組織血流量に対する 脱血負荷の影響

BDL- 1 : 胆管結禁 1 週, BDL- 3 : 胆管結禁 3 週

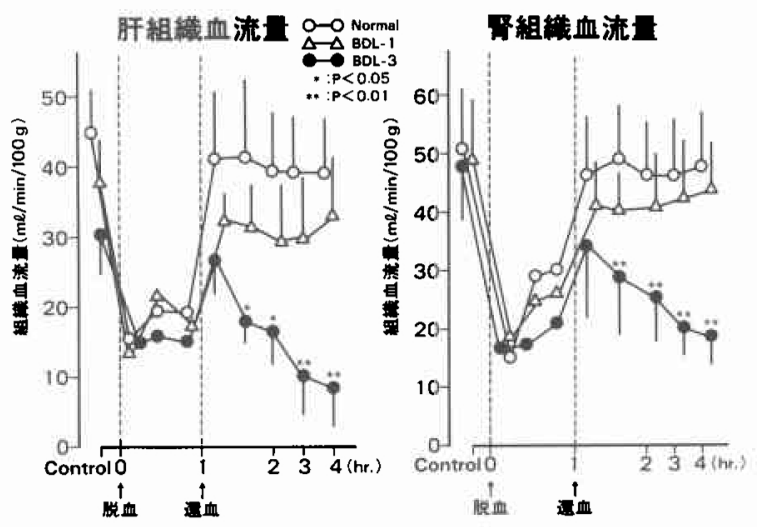

がみられた $(\mathrm{p}<0.01)$.

2）閉塞性黄疸モデル

肝組織血流量 $(\mathrm{ml} / \mathrm{min} / 100 \mathrm{~g}$ 体重) は正常群, 黄疸

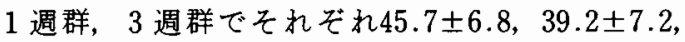
$33.5 \pm 7.5$ 之黄疸期間の延長に伴い低下した。腎組織血 流量に黄疸期間による差は認められなかった。正常群, 黄㡺 1 週間群での肝組織血流量は還血により，おのお の前值の $90 \% ， 83 \%$ に回復し 4 時間後まで良く保たれ ていた(図 3 )。一方，3 週群では還血30分後には55\% $(\mathrm{p}<0.05) ， 4$ 時間後には29\% $(\mathbf{p}<0.01)$ のみ, 回 復は不良であった.腎組織血流量の変化も同様であり, 3 週群では還血30分後には前値の60\% ( $\mathrm{p}<0.01) ， 4$

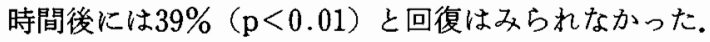
肝, 腎 Energy Chargy は正常群，1 週群では速やかに 回復したのに対し，3週群では和のおの0.73士 $0.04(\mathrm{p}<0.01), 0.76 \pm 0.04(\mathrm{p}<0.01)$ と回復は認め られなかった。

\section{考察}

術前肝機能正常例に括ける術後黄疸の発生頻度は $7.7 \%$ ありり, 術後15日以内に一過性の黄疸を呈した症 例の多くは黄疸は軽度で，なんらその誘因を指摘でき ず，㐿術侵襲，麻酔，出血，輸血，投与薬剤などのい くつかの因子が重なり合って生じていることを考える べきである.一方，術後ある程度の期間を経て発生し た黄渲は中等度以上のものが多い。それら症例の黄㾝 の誘因として, 膿瘍, 腹膜炎, 糈隔炎などの重症感染 症や出血性ショックなどが考光られた。強力な抗生物 質の長期間の投与，中心静脈栄盖などの訮障害への関 与を否定するものではないが，エンドトキシンによる 
肝障害，血圧低下に基づく肝血流の減少などに注目し たい. Norton ら ${ }^{2)}$ は術後肝不全73例中27例で主として 腹腔内感染症による敗血症が肝不全の主因となってい たと報告している。エンドトキンンの作用として主と して chemical mediatorを介しての組織血流量の低 下，および肝細胞に対する直接的な障害る指摘されて いる. Utili ら ${ }^{3}$ は肝灌流実験にて胆汁排泄量は灌流液 中メンドトキシン濃度と相関して減少し，その機序と して肝細胞からの胆汁分泌障害を考兄ている. Norton ら ${ }^{2)}$ は感染に起因した肝不全の死亡率は $37 \%$ 之他の原 因からなる肝不全の $80 \%$ に比較して低く，積極的な感 染巣のドレナージを治療法の第 1 選択にすべきである と述べている。

旰硬変合併例の術後黄疸発生頻度は高く, 特に高度 黄㾝をきたした症例に救命例はみられない，肝硬变症 では肝予備能が低下して招り, 術前に肝予備能の正確 な評価ができないことの多い緊急手術は可能な限り避 けるべきであり，やむを点ない場合です最小限の手術 侵襲にとどめるべきである。教室では食道離断術に関 して ICGK 值を中心とした手術適応基準を設定して いるが4)，その基準に適合すれば通常の腹部手術には 十分耐えらるものと考えている。しかし，再手術を要 したり，大量出血，感染症なぞの合併症が発生した場 合, 肝不全に陥る可能性は非硬変手術例に比較して極 めて高頻度である。肝硬変症に打いては肝ミトコンド リア機能の低下 ${ }^{5)}$ ともに網内系機能拉よび細胞性免 疫能 む低下しており ${ }^{2)}$, 感染症から容易に敗血症 MOF へと移行しやすい.エンドトキシン血症がさらに肝硬 変症の増悪因子となっているとの報告もみられ，ェン ドトキシン陽性例で腹水出現，消化管出血，腎不全の 発生頻度, さらに死亡率が高いとされている6 ${ }^{6}$. 肝硬变 合併肝癌に対する肝切除の直接成績を最む左右する因 子は術中出血量であった7)。肝切除による肝細胞量, Kupffer 細胞量の減少に加兄ての肝血流量の低下に基 づく残存肝の障害，出血による opsonin の低下による 網内系機能の低下などがその後の合併症発現，死亡に 関しているものと思われた。

また, 閉塞性黄病では肝・腎ミトコンドリア機能の 低下，肝不全因子，アンモニア処理能の低下など，肝 不全, 腎不全の準備状態にあるとされている8). また, 閉塞性黄疸手術例ではエンドトキシン血症が生じ9, その機序の一つとして胆汁酸塩の作用により抑制され ているェンドトキシンの腸粘膜の通過機構が破綻する との報告もみられる ${ }^{10}$. 出血, 感染を伴ら上らな手術侵
襲により肝不全，腎不全，DICなどを容易に合併する ことが示された。

実験的肝硬変症において, 脱血負荷後の還血により 動脈圧は回復しても肝組織血流量に回復はみられな かった。その理由として，肝の線維増生による類洞で の血流調節機能障害を基盤として，低血圧負荷時に増 加した血流抵抗が低血圧からの回復後にも正常化しに くく，エピネフリンに対する高反応性とあいまって肝 組織血流へベルでの回復が阻害されるものと推察され る。また，腎組織血流の回復障害の原因に関しても， 腎には光顕的な形態変化は認められないことから， ピネフリンに対する反応性など機能的因子の関与が考 えられるところである。

また，小山らは閉塞性黄疸ラットの肝ミトコンドリ ア機能を検討し，その呼吸指標は 1 週群で正常の $80 \%$, 3 週群で $60 \% ， 6$ 週群で30\%と黄疸期間の延長と伴に 低下寸るとし，また腎皮質ミトコンドリア機能も，肝 ほど著明ではないがほぼ平行して低下するとしてい る8).すなわち, 黄㾝短期例では土ネルギー産生の場で ある肝，腎ミトコンドリア機能の障害す軽度であるの に対し，黄庭長期例ではすでに機能不全準備状態にあ るといっても過言ではない，その状態に低血圧負荷が 加わった増合，肝，腎局所循環障害は回復し難い，以 上のことから, 肝硬変症や長期閉塞性黄疸例では組織 低還流状態を契機として Energy Chargeに表現され る肝，腎ェネルギー代謝が悪化し，肝不全，腎不全に 楩りやすいことが示唆された。

\section{おわりに}

当科で 3 年間に経験した症例を中心に術後黄疸につ いて検討した結果を報告した，術後黄疸の多くは軽度 であり一過性に 1 週間以内に軽減し，それらでは黄疸 の原因が明らかでないことが多い，一方，術後ある程 度の期間を経て高度黄疸に至る症例の予後は不良であ クそそれらは重症感染症を誘因することが多い，また， 旰硬变症, 肝切除, 閉塞性黄疸においては術後黄疸の 発生頻度は高くなり，出血を契機に肝不全に陷ること が多い，実験的検討では，肝硬変症や長期閉塞性黄㾝 では低血圧負荷後の肝，腎組織血流量の回復は不良で あり，その結果として肝，腎ェネルギー代謝不全に陥 クやすいことが示された，以上から，これら肝障害例 では肝障害度に応じた適切な術式を選択すべきであ り, 肝血流の低下, anoxia の招来は極力避けるべきで ある.また，感染巣に対する積極的なドレナージや， 高度黄㾝例では早期に血浆交換を考虑するなどの対策 
が必要である。

\section{文献}

1) Atkinson $\mathrm{DE}$ : The energy charge of adenylate pool as a regulatory parameter. Interaction with feedback modifiers. Biochemistry $7: 4030$ -4034, 1968

2) Norton L, Moore G, Eiseman B: Liver failure in the postoperative patient: The role of sepsis and immunologic deficiency. Surgery $78: 6-13$, 1975

3) Utili R, Abernathy CO, Zimmerman $\mathrm{HJ}$ : Cholestatic effects of Escherichia coli endotoxin. Endotoxin on the isolated perfused rat liver. Gastroenterology $70: 248-253,1976$

4) 大内清昭, 小山研二, 菊池 淳ほか: 肝硬変症を伴 5食道静脈溜に対する食道離断術の適応. 重回龽 分析を用いたリスクの判定. 外科 46：1029
$-1036,1984$

5）菊池淳, 小山研二, 大和田康夫ほか： Thioacetamide による実験的肝硬変の機能と形 態に関する研究。肝藏 $28: 53-61,1987$

6）多羅尾和郎：エンドトキシンと肝障害. 医のあゆ 文 $136: 1158-1163,1986$

7）大内清昭, 松原修二, 福原賢次ほか：肝癌における 肝切除術の啇応, 術前の risk 判定を中心に. 現代 医療 $20: 1217-1220,1988$

8）佐藤寿雄, 小山研二：閉塞性黄疸の病態生理. 肝障 害を中心として. 外科 $36: 426-433,1974$

9) Nakagawa $K$, Matsubara $S$, Ouchi $K$ et al : Endotoxemia after abdominal sugery. Tohoku J Exp Med 150:273-280, 1986

10)安倍弘彦, 中野均, 谷川久一：肝疾患とエンドト キシン血症. 肝・胆・膵 $12: 551-556,1986$ 